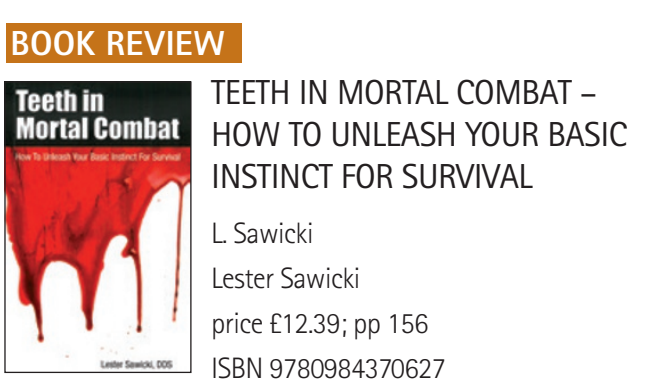

This book is a self-published title by Lester Sawicki, an American General Dental Practitioner and keen martial arts enthusiast. Sawicki seeks to explore the reasons why the human race has suppressed our 'most basic instinct' to use our teeth and jaws for self-defence. He also offers advice on how we can hone this instinct to our advantage in times of 'mortal combat'.

In the first section of the book the author relays his own personal theories on why modern man suppresses their primal instinct of biting for self-defence. He cites bruxism or 'theogenesis' as evidence that we are all subconsciously sharpening our teeth to make them more efficient for a 'stronger, deeper, and more lethal bite'. He goes so far as to praise any dentist who provides treatment to 'enhance teeth for times of mortal combat'.

The author's eastern philosophy influences are clearly evident in part two of the book. He devises an unconventional classification system for the masticatory system using Yin and Yang concepts. He describes the teeth as being the Yang, or male energy in the mouth and the tongue as the Yin or female energy. Again this section is littered with Sawicki's own personal theories which lack any scientific basis. For example, he believes that human beings are capable of expressing a third tooth bud and that this would allow for a 250 year human life span.

Part three and four are dedicated to descriptions of exercises that focus 'chi' energy on the teeth and jaws. The author claims that these exercises will improve fighting skills and overall health. Some of the recommendations are questionable at the very least and none are backed up with valid scientific references. He advises occlusal adjustment to alleviate jaw, head, neck and shoulder pain as well as 'tooth-tapping' and 'conscious clenching' to increase jaw and tooth strength. He also argues a case for banning mouth guards and helmets in contact sports claiming that if players were trained to use their 'chi' to protect themselves there would be fewer dento-alevolar injuries in sport. Surely not a recommendation to be followed!

In conclusion, this publication is difficult to recommend. The book has no real structure with the author tending to flit from topic to topic without any obvious or logical connection. There is no scientific evidence for any of the author's theories or recommendations and in fact there are numerous inaccuracies in the text. I was also a bit alarmed at the undertone of violence that permeates the book. Sawicki seems fixated on so-called 'mortal combat' and there are many gory descriptions of and metaphors for physical violence. It is aimed at a very niche audience and certainly will not appeal to most clinicians.

H. M. LANE

\section{NOTICE TO MEMBERS: BURGEONING BOOKS}

If any BDA member has dental textbooks in good condition that they no longer require and wish to dispose of, then the BDA Library would be happy to receive an email with a list of titles. Much as the library loves to receive gifts, regrettably, it cannot accept used textbooks without prior notification. As the most comprehensive dental library in Europe, its shelf space is severely limited due to

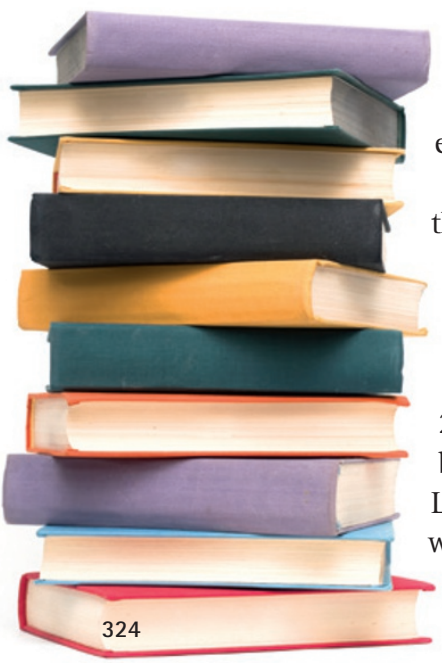
the fact that it holds copies of most dental books published. To contact the Library please email: library@bda.org.

Members are reminded that the Library has thousands of textbooks available for loan which can be posted out to members or collected from the Library. It also has around 250 dental eBooks which can be accessed remotely via the Library pages of the BDA's website at www.bda.org.

\section{SUMMER SEASON SEMINAR}

The seminar 'Dentistry 2015: primary care, public health, and the dental contract' will be held in Central London on 7 July 2015.

Delegates at the 2015 annual Westminster Health Forum seminar on next steps for dentistry will assess challenges and opportunities for those working in the industry for the year ahead and beyond. Sessions will focus on developments to the dental contract following the release of findings from the Department of Health consultation. Attendees will also consider the role of dentistry in primary care, and the key issues surrounding regulation, workforce
HONOURS, AWARDS, APPOINTMENTS

Bursary Award Winners

The winners of the Association of Dental Groups (ADG) 2015 Postgraduate Bursary Award were Orna Ni Choileain and Niall McGoldrick for their project Let's Talk About Mouth Cancer. Rosie Pritchett, Corwin Hine, Mark Franks and Luke Fisher-Brown were the Undergraduate (Management) Gold Award Winners, and Amardeep Singh Dhadwal was Undergraduate (Professionalism) Gold Award Winner.

Deborah Evans received the Undergraduate Management Silver Award; Kirun Ray the Undergraduate Management Bronze Award; Lewis Olsson the Undergraduate Professionalism Silver Award and Gemma Wheeler the Undergraduate Professionalism Bronze Award.

\section{New BLOS Chair}

Ian Hutchinson has been appointed new Chair of the British Lingual Orthodontic Society. Dr Hutchinson is a clinical director at Wire Orthodontic Laboratory and Chief of Orthodontics for DoooX - an online learning platform. development, clinical engagement, and public dental health.

A keynote address will be delivered by a senior representative at NHS England and a wide range of prestigious speakers have agreed to speak at the event, including Dr Helen Falcon, Professor Rebecca Harris, Rupert Hoppenbrouwers and Sampana Banga.

More information about the event, which is CPD-certified, can be found at http://www.westminsterforumprojects.co.uk/forums/ event.php?eid=956\&t $=9902$.

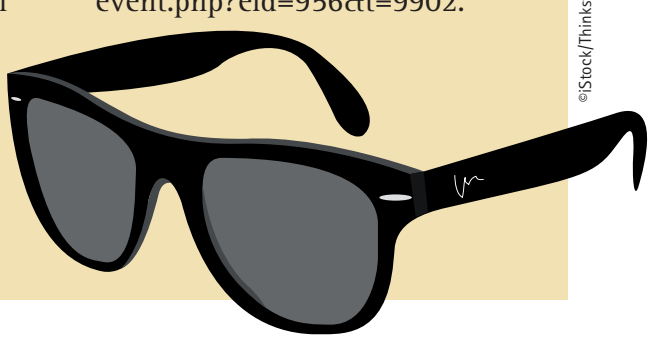

